\title{
Lung Cytokine Gene Expression is Correlated with Increased Severity of Disease in a Novel H4N8 Influenza Virus Isolated from Shorebirds
}

\author{
Yasuha ARAI ${ }^{1)}$, Vuong N. BUI ${ }^{1)}$, Yohei TAKEDA ${ }^{1)}$, Dai Q. TRINH ${ }^{1)}$, Sayo NIBUNO ${ }^{1)}$, Jonathan RUNSTADLER ${ }^{2)}$, \\ Haruko OGAWA $^{1) *}$ and Kunitoshi IMAI ${ }^{1)}$ \\ 1) Research Center for Animal Hygiene and Food Safety, Obihiro University of Agriculture and Veterinary Medicine, Obihiro, Hokkaido \\ 080-8555, Japan \\ 2)Department of Biological Engineering and Division of Comparative Medicine, Massachusetts Institute of Technology, Cambridge, MA \\ 02139, U.S.A.
}

(Received 22 April 2013/Accepted 29 May 2013/Published online in J-STAGE 12 June 2013)

ABSTRACT. The lung cytokine gene expression profiles of mice infected with 2 strains of H4N8 viruses isolated from shorebirds and reference H4 viruses from ducks are compared. Major differences between the two H4N8 strains of shorebirds, one of which causes a severe respiratory disease in mice, are in the PB1 and NS1 genes. In mice with H4N8 virus induced pneumonia, overall expression of TNF- $\alpha$, IL-6 and IL-12 genes was markedly higher than in mice infected with other H4 viruses tested, although gene expression of type I interferon was not increased until day 4 post viral infection. In contrast, in mice infected with a comparison H4N8 strain, gene expression of type I interferon peaked on day 1 post viral infection. Overall, the cytokine response corresponds with the severity of disease caused by shorebird H4N8 virus. The results obtained in this study provide valuable information to understand the immunopathology induced by a low pathogenic avian influenza virus, which may be useful in preparation for outbreaks of novel influenza A virus

KEY WORDS: avian influenza virus, cytokine, H4N8, mouse, pathogenicity.

doi: 10.1292/jvms.13-0201; J. Vet. Med. Sci. 75(10): 1341-1347, 2013

Interspecies transmission of Influenza A virus has been a major concern for public health worldwide, since the first human cases of the H5N1 highly pathogenic avian influenza virus (HPAIV) were reported in Hong Kong in 1997. Heightened concern was elevated with knowledge that a direct chicken-to-human transmission of the virus occurred without having an intermediate host, such as pigs [2]. Concern over direct transmission of AIV to humans seemed to be further confirmed in the recent human cases of H7N9 AIV infection, which include many fatal cases [36]. Previous studies have reported that AIVs, including those from wild birds, could naturally infect and cause disease in a variety of mammalian species $[13,18,19,29]$. In experimental settings, AIVs isolated from wild birds have productively infected and induced lesions in the respiratory tissues of mammalian hosts, such as mice and ferrets without requiring any adaptations to the host species $[1,6,10,15]$. Transmission of wild viral strains via direct contact in ferrets was also reported, suggesting that AIVs carried by aquatic birds can potentially infect and transmit in humans and other mammals without adaptation $[7,34]$. It should be noted that many of these AIV strains replicated efficiently in mouse lungs even in the absence of any lesions in tissues, although some strains caused pulmonary lesions $[1,6]$. These results suggest that factors, such

\footnotetext{
*Correspondence to: Ogawa, H., Research Center for Animal Hygiene and Food Safety, Obihiro University of Agriculture and Veterinary Medicine, 2-11 Inada, Obihiro, Hokkaido 080-8555, Japan.

e-mail: hogawa@obihiro.ac.jp

(C)2013 The Japanese Society of Veterinary Science
}

as the character of the host immune response, induced by infection, are involved in the extent of viral pathogenicity.

Upon infection with influenza virus, innate immune response promotes the release of proinflammatory cytokines and chemokines as a part of an inflammatory response in the host. Although proinflammatory cytokines are necessary for virus clearance, cytokine dysregulation, sometimes referred to as a "cytokine storm", contributes to disease severity. Severe cases of human disease caused by H5N1 virus or pandemic H1N1 2009 virus involved viral pneumonia associated with just such a cytokine storm [20, 23]. Furthermore, proinflammatory cytokine levels in the blood stream of humans infected with H5N1 virus were much higher than those of humans infected with seasonal influenza virus [23]. Similarly, in mouse studies, H5N1 infection resulted in elevated levels of proinflammatory cytokines and chemokines in mouse lungs [24]. In addition to such inflammatory responses, innate immune mechanisms in viral infection induce antiviral host responses. Cytokines, such as type I interferons (IFNs), inhibit viral replication in a variety of pathways in host cells. On the other hand, to replicate more efficiently in host cells, viruses have developed mechanisms to abrogate these antiviral host immune responses. Pathogenicity in influenza infection therefore depends on a combination of virally induced up or down-regulation of host immune mechanisms, implicating a combination of virus and host factors in disease severity $[17,21]$.

We recently reported that the H4N8 subtype virus isolated in our AIV surveillance study in wild birds, A/slaty-backed gull/Japan/6KS0185/2006 (6KS0185), caused severe respiratory disease in mice [1]. The H4N8 isolate was genetically highly related to A/red-necked stint/Australia/1/04 (Aus04) 
Table 1. Probe and primer sets (Taqman MGB, Applied Biosystems) used in real-time RT-PCR

\begin{tabular}{lc}
\hline \multicolumn{1}{c}{ Gene name } & Product number \\
\hline TNF- $\alpha$ (Tumor necrosis factor alpha) & Mm00443528_m1 \\
IL-6 (Interleukin 6) & Mm00446190_m1 \\
IL-12 (Interleukin 12 alpha) & Mm00434165_m1 \\
IFN- $\alpha 11,2$ (Interferon alpha11, 2) & Mm04207507_Gh \\
IFN- $\beta 1$ (Interferon beta1) & Mm00439546_sl \\
IFN- $\gamma$ (Interferon gamma) & Mm01168134_ml \\
Eukaryotic 18S rRNA (Internal control) & ABI433860F \\
\hline
\end{tabular}

[14], except for significant differences in the PB1 and NS gene segments. Both 6KS0185 and Aus04 proliferated in mouse lungs to a similar level, but only 6KS0185 caused severe respiratory disease in mice [1]. These results suggested that other factors, in addition to the efficiency of viral replication, such as the character of the host immune responses, were involved in the pathogenicity of 6KS0185 in experimentally infected mice. In order to elucidate the role of host immune responses in this disease severity, we investigated the cytokine profiles in the lungs of mice infected with $6 \mathrm{KS} 0185$ in comparison with those with infected with Aus04, A/duck/Osaka/1/05 (H4N8) (Osaka05), A/duck/Shiga/8/04 (H4N6) (Shiga04) and A/duck/Czechoslovakia/56 (H4N6) (Czech56), all of which do not cause any clinical symptoms in infected mice.

\section{MATERIALS AND METHODS}

Viruses: 6KS0185 (H4N8), which was isolated from a gull fecal sample in our surveillance study [1], was used in this study. Aus04 (H4N8) was kindly provided by Dr. Aeron Hurt at the WHO Collaborating Centre for Reference and Research on Influenza and the Victorian Infectious Diseases Reference Laboratory. Osaka05 (H4N8) and Shiga04 (H4N6) were kindly provided by the National Institute of Animal Health, Japan. Czech56 (H4N6) was supplied by Dr. H. Kida at the OIE Reference Laboratory for HPAI at Hokkaido University, Japan. The seed viruses were propagated in the allantoic cavity of 10-day-old embryonated chicken eggs for only one passage, and aliquots of the allantoic fluids containing the viruses were stored at $-80^{\circ} \mathrm{C}$ until use.

Mouse lung samples obtained in the infection study: The lung homogenate samples obtained in the mouse infection study, which was described in our previous paper [1], were used in this study. In the study, 8- to 10-week-old female $\mathrm{BALB} / \mathrm{c}$ mice were intranasally infected with 6KS0185, Aus04, Osaka05, Shiga04 or Czech56 at a dose of $10^{3} \mathrm{TCID}_{50}$ ( $\mathrm{n}=15$ in each group) in $50 \mu \mathrm{l}$ of allantoic fluid. One group of mice, which received phosphate buffered saline, served as a control group. On 1, 2, 3, 4, 5 and 7 days post infection (dpi), mice were sacrificed, and lungs were obtained from the mice and processed as a $10 \%$ homogenate preparation [1]. Total RNA was isolated from the lung homogenate samples by using ISOGEN-LS (Nippon Gene, Tokyo, Japan) and subjected to a real-time reverse transcription-PCR (RRT-PCR) for the
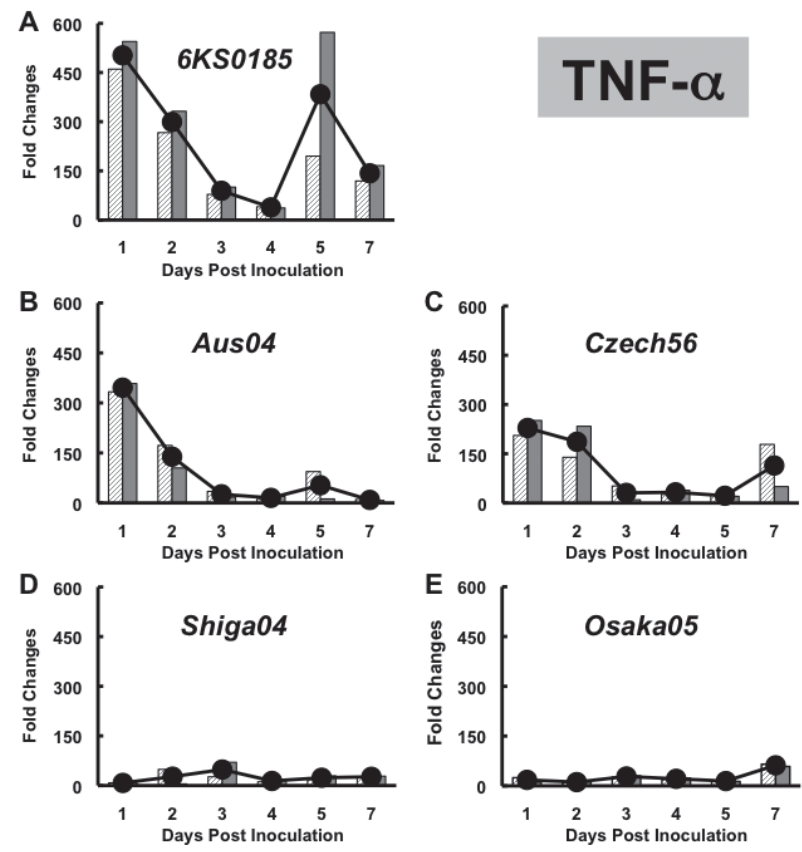

Fig. 1. TNF- $\alpha$ gene expression profiles in lungs of the mice infected with $\mathrm{H} 4$ subtype viruses. (A) A/slaty-backed gull/ Japan/6KS0185/2006 (H4N8), (B) A/red-necked stint/Australia/1/04 (H4N8), (C) A/duck/Czechoslovakia/56 (H4N6), (D) A/ duck/Shiga/8/04 (H4N6), (E) A/duck/Osaka/1/05 (H4N8). RRTPCR was performed to measure TNF- $\alpha$ mRNA levels. The Ct values were normalized to $18 \mathrm{~S}$ rRNA and calculated as fold changes in relation to the mRNA obtained from uninfected normal mice by the comparative $\mathrm{C}(\mathrm{T})$ method. The mean fold changes (closed circles) were calculated from the results of two mice (striped bar and gray bar).

quantification of lung cytokine levels. All mouse studies were conducted in compliance with the institutional rules for the care and use of laboratory animals and using protocols approved by the relevant committee at the University.

$c D N A$ synthesis and RRT-PCR: Isolated RNA was converted to cDNA using random primers (Invitrogen, Carlsbad, CA, U.S.A.), and M-MLV reverse transcriptase (Invitrogen). Reverse transcription reactions were carried out under the following conditions: $25^{\circ} \mathrm{C}$ for $10 \mathrm{~min}, 37^{\circ} \mathrm{C}$ for $60 \mathrm{~min}$ and $60^{\circ} \mathrm{C}$ for $10 \mathrm{~min}$. The RRT-PCR was performed in an ABI PRISM 7900HT Sequence Detection System (Applied Biosystems, Foster City, CA, U.S.A.) by TaqMan probe assay using the synthesized cDNA and EagleTaq Master Mix With ROX (Roche Applied Science, Penzberg, Germany). To measure cytokine mRNA levels in the samples, Taqman MGB probe and primer sets (Applied Biosystems) listed in Table 1 were used. A PCR cycle used was as follows: $95^{\circ} \mathrm{C}$ for $15 \mathrm{sec}, 45 \mathrm{cycles}$ of $95^{\circ} \mathrm{C}$ for $15 \mathrm{sec}$ and $60^{\circ} \mathrm{C}$ for $1 \mathrm{~min}$. The threshold cycle $(\mathrm{Ct})$ was defined as the number of cycles required for the fluorescent signal to cross the threshold. The $\mathrm{Ct}$ values were normalized to $18 \mathrm{~S}$ rRNA and calculated as fold changes in relation to the RNA sample obtained from uninfected mice. The results were expressed as fold induc- 

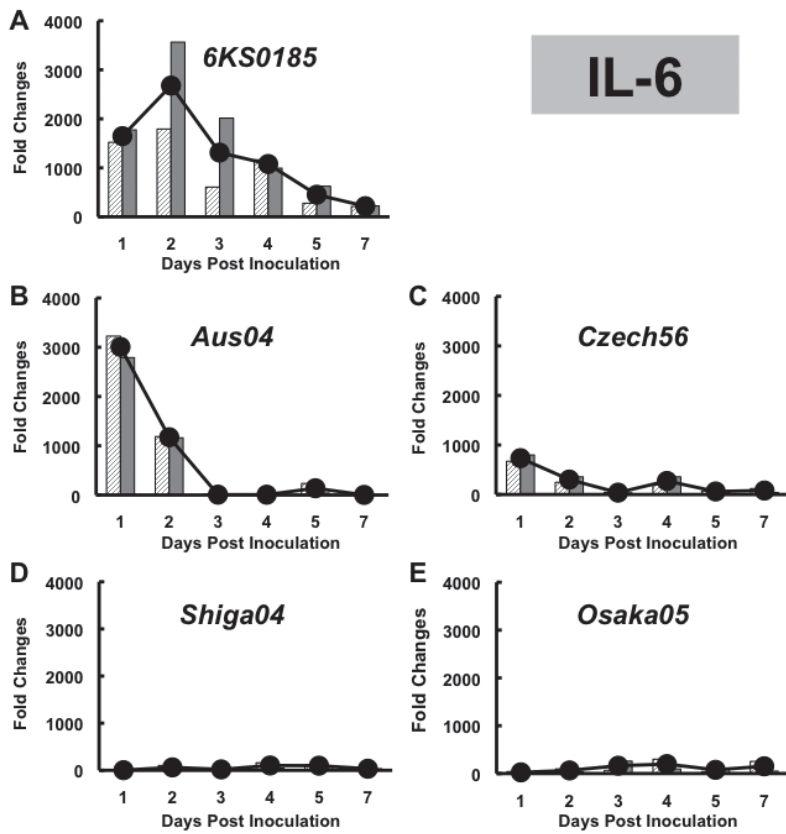

Fig. 2. IL-6 gene expression profiles in lungs of the mice infected with H4 subtype viruses. (A) A/slaty-backed gull/ Japan/6KS0185/2006 (H4N8), (B) A/red-necked stint/Australia/1/04 (H4N8), (C) A/duck/Czechoslovakia/56 (H4N6), (D) A/ duck/Shiga/8/04 (H4N6), (E) A/duck/Osaka/1/05 (H4N8). RRTPCR was performed to measure IL-6 mRNA levels. The Ct values were normalized to $18 \mathrm{~S}$ rRNA and calculated as fold changes in relation to the mRNA obtained from uninfected normal mice by the comparative $\mathrm{C}(\mathrm{T})$ method. The mean fold changes (closed circles) were calculated from the results of two mice (striped bar and gray bar).

tion of gene expression (relative quantity of template) using the comparative $\mathrm{C}(\mathrm{T})$ method [25].

\section{RESULTS}

Proinflammatory cytokine expression was elevated in 6 KS0185 infected mice: In lungs of the mice infected with $6 \mathrm{KS} 0185$, TNF- $\alpha$ gene expression was elevated to the highest level among all the samples tested in this study at $1 \mathrm{dpi}$. The TNF- $\alpha$ gene expression decreased gradually to nearly normal levels at $4 \mathrm{dpi}$, but again increased dramatically on 5 to 7 dpi when it again decreased, thus showing a biphasic pattern of expression change in the 6KS0185-infected mouse lungs. Similarly, in lungs of the mice infected with Aus04 and Czech56, TNF- $\alpha$ gene expression was elevated on 1 dpi, albeit not to as high a level as in the 6KS0185-infected mice. The TNF- $\alpha$ gene expression level decreased gradually until 3 dpi in these mice, and only slightly increased on 5 or $7 \mathrm{dpi}$. In contrast, changes in TNF- $\alpha$ gene expression were marginal in lungs of the mice infected with Shiga04 and Osaka05 during 1-7 dpi (Fig. 1). Similarly to TNF- $\alpha$, gene expression of IL-6 was markedly elevated at 1 dpi in lungs of the mice infected with $6 \mathrm{KS} 0185$ and Aus04. In the 6KS0185-infected mice, the IL-6 gene expression further increased on 2 dpi and then

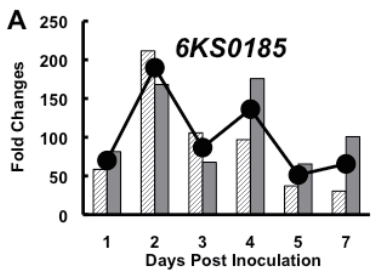

IL-12
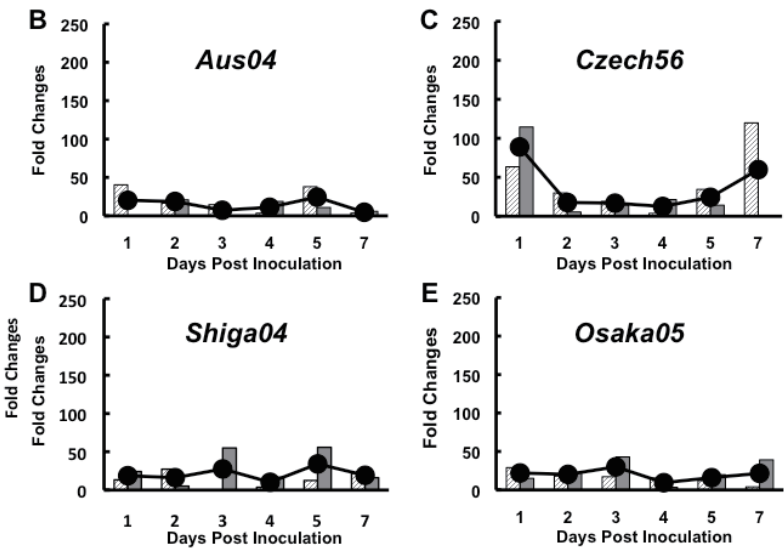

Fig. 3. IL-12 gene expression profiles in lungs of the mice infected with H4 subtype viruses. (A) A/slaty-backed gull/ Japan/6KS0185/2006 (H4N8), (B) A/red-necked stint/Australia/1/04 (H4N8), (C) A/duck/Czechoslovakia/56 (H4N6), (D) A/ duck/Shiga/8/04 (H4N6), (E) A/duck/Osaka/1/05 (H4N8). RRTPCR was performed to measure IL-12 mRNA levels. The Ct values were normalized to $18 \mathrm{~S}$ rRNA and calculated as fold changes in relation to the mRNA obtained from uninfected normal mice by the comparative $\mathrm{C}(\mathrm{T})$ method. The mean fold changes (closed circles) were calculated from the results of two mice (striped bar and gray bar).

decreased gradually to the normal level by $7 \mathrm{dpi}$, whereas in lungs of the mice infected with Aus04, the elevated level of IL-6 gene expression decreased to the normal level on 3 dpi. Elevation of IL-6 gene expression was observed in lungs of the mice infected with Czech56 at lesser levels compared to those in the mice infected with 6KS0185 and Aus04 and only slightly elevated in the mice infected with the other 2 viruses (Fig. 2). In the 6KS0185-infected mice, IL-12 gene expression levels increased on $1 \mathrm{dpi}$ and remained elevated until $7 \mathrm{dpi}$, during which the highest level was observed on 2 dpi. Moderate changes were observed in the IL-12 gene expression of Czech56-infected mice, but only minor changes were observed in other groups including the Aus04-infected mice (Fig. 3).

Antiviral cytokine expression was elevated slowly in 6KS0185-infected mice: In the 6KS0185-infected mice, IFN- $\alpha$ gene expression did not markedly change until 3 dpi, but drastically increased on $4 \mathrm{dpi}$. In contrast, the expression level of IFN- $\alpha$ in the mice infected with Aus04 peaked on $1 \mathrm{dpi}$ and dropped to the normal level on 3 dpi. IFN- $\alpha$ gene expression was not detected in the mice infected with Osaka05, Shiga04 and Czech56 throughout the period tested (Fig. 4). The kinetics of IFN- $\beta$ gene expression were quite similar to those of IFN- $\alpha$ gene expression in all the groups 

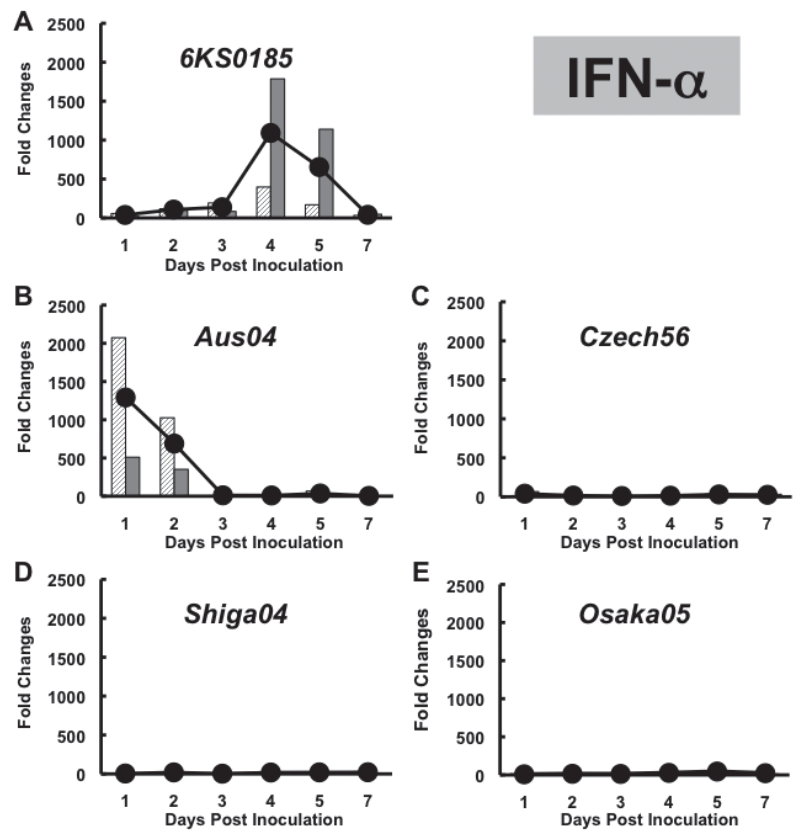

Fig. 4. IFN- $\alpha$ gene expression profiles in lungs of the mice infected with $\mathrm{H} 4$ subtype viruses. (A) A/slaty-backed gull/ Japan/6KS0185/2006 (H4N8), (B) A/red-necked stint/Australia/1/04 (H4N8), (C) A/duck/Czechoslovakia/56 (H4N6), (D) A/ duck/Shiga/8/04 (H4N6), (E) A/duck/Osaka/1/05 (H4N8). RRTPCR was performed to measure IFN- $\alpha$ mRNA levels. The Ct values were normalized to $18 \mathrm{~S}$ rRNA and calculated as fold changes in relation to the mRNA obtained from uninfected normal mice by the comparative $\mathrm{C}(\mathrm{T})$ method. The mean fold changes (closed circles) were calculated from the results of two mice (striped bar and gray bar).

tested (Fig. 5). IFN- $\gamma$ gene expression level clearly increased only in the 6KS0185- and Czech56-infected mice on 5 and 7 dpi, respectively (Fig. 6).

\section{DISCUSSION}

In this study, lung cytokine gene expression profiles were compared between the mice infected with 6KS0185 and those infected with Aus04 and other H4 subtype viruses. Among the viruses, only $6 \mathrm{KS} 0185$ caused respiratory disease in the infected mice, although all the viruses proliferated in the lungs of infected mice to a similar level [1].

In the lungs of 6KS0185-infected mice, gene expression levels of the proinflammatory cytokines, TNF- $\alpha$ and IL-6, were higher than those of the mice infected with Aus04 and other H4 subtype viruses at most time points measured (Figs. 1 and 2). IL-6 is reportedly elevated in patients with severe clinical symptoms of influenza and correlates with disease severity in early stages of infection [16], suggesting that the successive high level of IL-6 production in the lungs (Fig. 2A) of mice infected with 6KS0185 is related to the severity of respiratory disease in these mice. Interestingly, TNF- $\alpha$ gene expression showed a biphasic pattern in the mice infected with 6KS0185 (Fig. 1A). TNF- $\alpha$ is known
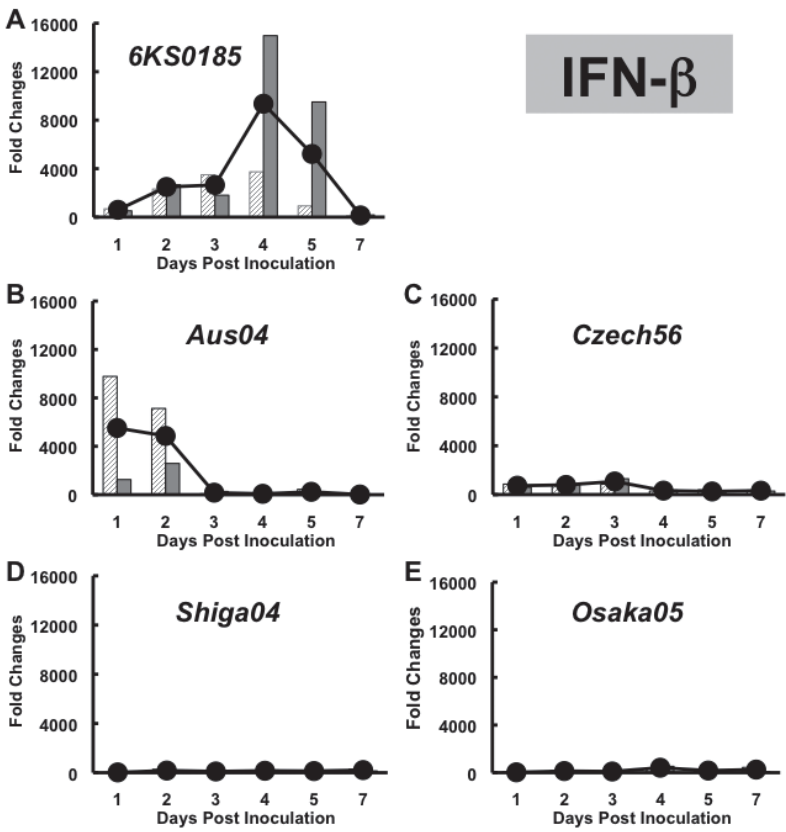

Fig. 5. IFN- $\beta$ gene expression profiles in lungs of the mice infected with H4 subtype viruses. (A) A/slaty-backed gull/ Japan/6KS0185/2006 (H4N8), (B) A/red-necked stint/Australia/1/04 (H4N8), (C) A/duck/Czechoslovakia/56 (H4N6), (D) A/ duck/Shiga/8/04 (H4N6), (E) A/duck/Osaka/1/05 (H4N8). RRTPCR was performed to measure IFN- $\beta$ mRNA levels. The Ct values were normalized to $18 \mathrm{~S}$ rRNA and calculated as fold changes in relation to the mRNA obtained from uninfected normal mice by the comparative $\mathrm{C}(\mathrm{T})$ method. The mean fold changes (closed circles) were calculated from the results of two mice (striped bar and gray bar).

to induce cell death and further promotes other cytokine production and immune cell migration [26]. Studies using cytokine receptor deficient mice suggested that TNF- $\alpha$ contributed to morbidity during H5N1 virus infection [31]. On the other hand, TNF- $\alpha$ is also critical for negative regulation of lung immunopathology during acute influenza infection [5]. The biphasic pattern of TNF- $\alpha$ gene expression that was observed in this study could correlate with the accelerated inflammatory reactions in the lungs, which in turn, proves beneficial for eventual recovery. In fact, the mice infected with 6KS0185 developed marked body weight reduction and severe symptoms of dyspnea, but most of these mice recovered successfully within 2 weeks post infection [1].

IL-12 is primarily produced by macrophages and dendritic cells and enhances cytotoxic activity of NK cells and $\mathrm{T}$ cells including CD8+ cytotoxic T lymphocytes (CTLs). In addition, IL-12 is an initial inducer of IFN- $\gamma$ production in NK cells and T cells in response to influenza infection [22, 35]. NK cells and CTLs activated by IL-12 are necessary to control virus spread via direct lysis of the infected cells or by the production of cytokines, such as IFN- $\gamma$ and TNF- $\alpha$, but these mechanisms may also contribute to pulmonary damage [33]. Thus, the high levels of IL-12 production may also contribute to the severe pneumonia of mice infected with 

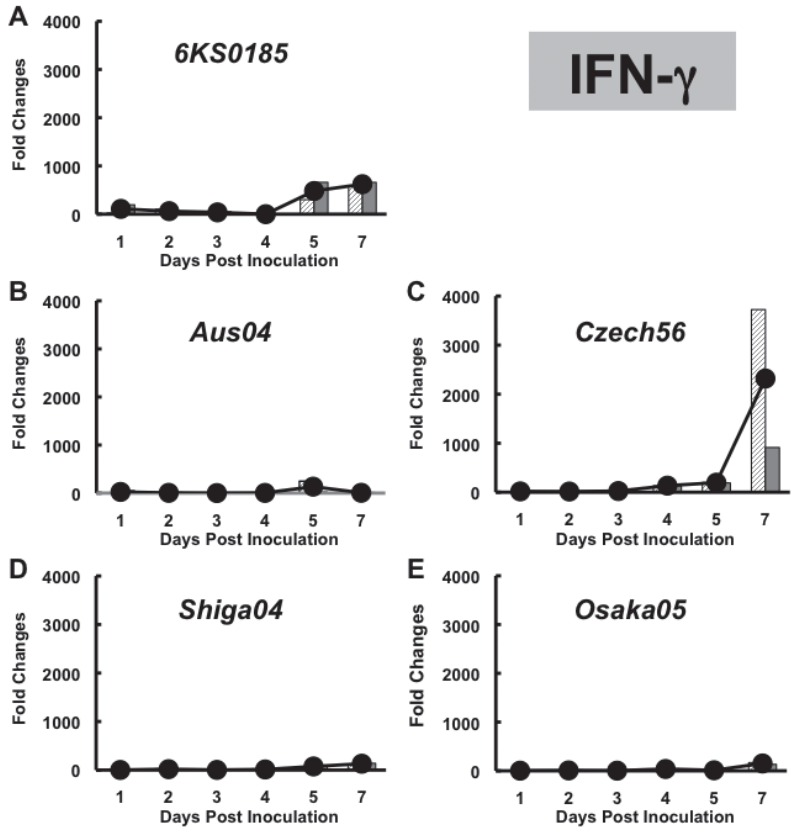

Fig. 6. Comparison of IFN- $\gamma$ gene expression profiles in lungs of the mice infected with $\mathrm{H} 4$ subtype viruses. (A) A/slaty-backed gull/Japan/6KS0185/2006 (H4N8), (B) A/red-necked stint/Australia/1/04 (H4N8), (C) A/duck/Czechoslovakia/56 (H4N6), (D) A/ duck/Shiga/8/04 (H4N6), (E) A/duck/Osaka/1/05 (H4N8). RRTPCR was performed to measure IFN- $\gamma$ mRNA levels. The Ct values were normalized to $18 \mathrm{~S}$ rRNA and calculated as fold changes in relation to the mRNA obtained from uninfected normal mice by the comparative $\mathrm{C}(\mathrm{T})$ method. The mean fold changes (closed circles) were calculated from the results of two mice (striped bar and gray bar).

6KS0185. On the other hand, direct correlations between the gene expression levels of IL-12 and those of IFN- $\gamma$ and TNF- $\alpha$ could not be confirmed in the current study (Figs. 1, 3 and 6), suggesting a need for additional studies to clarify the relationship between the IL-12 production and disease development in the mice infected with $6 \mathrm{KS} 0185$.

Type I IFNs are known to inhibit viral replication [17], and numerous in vivo studies have demonstrated that influenza virus replication is affected by type I IFNs [8]. In the mice infected with $6 \mathrm{KS} 0185$, virus titers in the lungs showed a biphasic pattern, which peaked on 1 dpi and 4 or 5 dpi [1]. It is unclear, given our data showing type I IFN production suppressed until $4 \mathrm{dpi}$ in the 6KS0185-infected mice (Figs. 4A and 5A) why virus titers decline during 2 to 3 $\mathrm{dpi}$, and it deserves further investigation. On the other hand, it has been reported that TNF- $\alpha$ can exert strong antiviral activity against influenza virus, and the antiviral effect could be greater than that of type I IFNs [27]. The high levels of IL-12 production in the 6KS0185-infected mice (Fig. 3A) might be activating NK cells and promoting the death of virus-infected cells for viral clearance as described above, particularly at early time points. Thus, the kinetics of virus titers in the mice infected with $6 \mathrm{KS} 0185$ could be affected not only by the production of type I IFNs, but also by other host immune factors including the production of other critical cytokines. Additional studies would further clarify the mechanism underlying the disease development in the mice infected with 6KS0185. Nevertheless, the results obtained in the current study suggested production of proinflammatory cytokines and suppressed levels of type I IFN in the 6KS0185 infected mice: thus, a correlation between the lung cytokine production and the severity of disease in the mice infected with a low pathogenic AIV of H4N8 subtype.

$6 \mathrm{KS} 0185$ was genetically different from Aus04 only in the PB1 and NS gene segments [1]. The differences in the PB1 and NS genes might contribute to the differences observed in the cytokine responses induced by $6 \mathrm{KS} 0185$ and Aus04. The PB1 and NS segments encode the PB1 and PB1F2 proteins and the NS1 and NS2 proteins, respectively. It is known that a major function of NS1 is to inhibit innate immunity by preventing type I IFN release $[11,12]$. In human lung epithelial cells, the NS1 of the 1918 pandemic virus efficiently suppressed the expression of IFN-regulated genes, which was likely to contribute to pathogenesis of the virus by controlling antiviral innate immune responses [9]. It is also known that PB1-F2 induces apoptosis in cells through the mitochondrial pathway [3] and inhibits the induction of type I IFNs in a different signaling cascade from that of NS1 [32]. Although several genetic mutations for these viral proteins that influence viral pathogenicity in the host have been reported $[4,28,30]$, these mutations could not be found in the genes of the $6 \mathrm{KS} 0185$ virus [1]. The results would suggest that other genetic mutations involved in the PB1 and NS genes of $6 \mathrm{KS} 0185$ might relate to the pathogenicity of the virus. A further study using a reverse genetics system would be useful to elucidate the actual role of viral factors involved in the pathogenesis of $6 \mathrm{KS} 0185$. In addition, characterization of the types of immune cells playing a role in host immune response by investigating bronchoalveolar lavage fluid in mice may help explain the cytokine profiles observed in this study. Although additional studies are needed, the results obtained in this study provide valuable information to understand the immunopathology induced by a low pathogenic AIV, which may be useful in preparation for outbreaks of novel influenza A virus.

ACKNOWLEDGMENTS. We are grateful to Sachiko Matsuda for technical assistance. This work was partially supported by grants from the Program of Founding Research Centers for Emerging and Reemerging Infectious Diseases, and by a Grant-in-Aid for Exploratory Research (19659115) from the Ministry of Education, Culture, Sports, Science and Technology (MEXT), Japan. This work was also partially supported by the US National Institute of Allergy and Infectious Diseases (NIAID contracts HHSN266200700009C and HHSN266200700007C).

\section{REFERENCES}

1. Bui, V. N., Ogawa, H., Xininigen, Karibe, K., Matsuo, K., Awad, S. S., Minoungou, G. L., Yoden, S., Haneda, H., Ngo, L. H., 
Tamaki, S., Yamamoto, Y., Nakamura, K., Saito, K., Watanabe, Y., Runstadler, J., Huettmann, F., Happ, G. M. and Imai, K. 2012. H4N8 subtype avian influenza virus isolated from shorebirds contains a unique PB1 gene and causes severe respiratory disease in mice. Virology 423: 77-88. [Medline] [CrossRef]

2. Chan, P. K. 2002. Outbreak of avian influenza $A(H 5 N 1)$ virus infection in Hong Kong in 1997. Clin. Infect. Dis. 34: S58-S64. [Medline] [CrossRef]

3. Chen, W., Calvo, P. A., Malide, D., Gibbs, J., Schubert, U., Bacik, I., Basta, S., O’Neill, R., Schickli, J., Palese, P., Henklein, P., Bennink, J. R. and Yewdell, J. W. 2001. A novel influenza A virus mitochondrial protein that induces cell death. Nat. Med. 7: 1306-1312. [Medline] [CrossRef]

4. Conenello, G. M., Zamarin, D., Perrone, L. A., Tumpey, T. and Palese, P. 2007. A single mutation in the PB1-F2 of H5N1 (HK/97) and 1918 influenza A viruses contributes to increased virulence. PLoS Pathog. 3: 1414-1421. [Medline] [CrossRef]

5. Damjanovic, D., Divangahi, M., Kugathasan, K., Small, C. L., Zganiacz, A., Brown, E. G., Hogaboam, C. M., Gauldie, J. and Xing, Z. 2011. Negative regulation of lung inflammation and immunopathology by TNF- $\alpha$ during acute influenza infection. Am. J. Pathol. 179: 2963-2976. [Medline] [CrossRef]

6. Driskell, E. A., Jones, C. A., Stallknecht, D. E., Howerth, E. W. and Tompkins, S. M. 2010. Avian influenza virus isolates from wild birds replicate and cause disease in a mouse model of infection. Virology 399: 280-289. [Medline] [CrossRef]

7. Driskell, E. A., Pickens, J. A., Humberd-Smith, J., Gordy, J. T., Bradley, K. C., Steinhauer, D. A., Berghaus, R. D., Stallknecht, D. E., Howerth, E. W. and Tompkins, S. M. 2012. Low pathogenic avian influenza isolates from wild birds replicate and transmit via contact in ferrets without prior adaptation. PLoS One 7: e38067. [Medline] [CrossRef]

8. Durbin, J. E., Fernandez-Sesma, A., Lee, C. K., Rao, T. D., Frey, A. B., Moran, T. M., Vukmanovic, S., García-Sastre, A. and Levy, D. E. 2000. Type I IFN modulates innate and specific antiviral immunity. J. Immunol. 164: 4220-4228. [Medline]

9. Geiss, G. K., Salvatore, M., Tumpey, T. M., Carter, V. S., Wang, X., Basler, C. F., Taubenberger, J. K., Bumgarner, R. E., Palese, P., Katze, M. G. and García-Sastre, A. 2002. Cellular transcriptional profiling in influenza A virus-infected lung epithelial cells: the role of the nonstructural NS1 protein in the evasion of the host innate defense and its potential contribution to pandemic influenza. Proc. Natl. Acad. Sci. U.S.A. 99: 10736-10741. [Medline] [CrossRef]

10. Gillim-Ross, L., Santos, C., Chen, Z., Aspelund, A., Yang, C. F., Ye, D., Jin, H., Kemble, G. and Subbarao, K. 2008. Avian influenza $\mathrm{H} 6$ viruses productively infect and cause illness in mice and ferrets. J. Virol. 82: 10854-10863. [Medline] [CrossRef]

11. Hale, B. G., Randall, R. E., Ortín, J. and Jackson, D. 2008. The multifunctional NS1 protein of influenza A viruses. J. Gen. Virol. 89: 2359-2376. [Medline] [CrossRef]

12. Hayman, A., Comely, S., Lackenby, A., Hartgroves, L. C., Goodbourn, S., McCauley, J. W. and Barclay, W. S. 2007. NS1 proteins of avian influenza A viruses can act as antagonists of the human alpha/beta interferon response. J. Virol. 81: 2318-2327. [Medline] [CrossRef]

13. Hinshaw, V. S., Webster, R. G., Easterday, B. C. and Bean, W. J. Jr. 1981. Replication of avian influenza A viruses in mammals. Infect. Immun. 34: 354-361. [Medline]

14. Hurt, A. C., Hansbro, P. M., Selleck, P., Olsen, B., Minton, C., Hampson, A. W. and Barr, I. G. 2006. Isolation of avian influenza viruses from two different transhemispheric migratory shorebird species in Australia. Arch. Virol. 151: 2301-2309. [Medline]
[CrossRef]

15. Joseph, T., McAuliffe, J., Lu, B., Jin, H., Kemble, G. and Subbarao, K. 2007. Evaluation of replication and pathogenicity of avian influenza a $\mathrm{H} 7$ subtype viruses in a mouse model. J. Virol. 81: 10558-10566. [Medline] [CrossRef]

16. Kaiser, L., Fritz, R. S., Straus, S. E., Gubareva, L. and Hayden, F. G. 2001. Symptom pathogenesis during acute influenza: interleukin-6 and other cytokine responses. J. Med. Virol. 64: 262-268. [Medline] [CrossRef]

17. Katze, M. G., He, Y. and Gale, M. Jr. 2002. Viruses and interferon: a fight for supremacy. Nat. Rev. Immunol. 2: 675-687. [Medline] [CrossRef]

18. Keawcharoen, J., Oraveerakul, K., Kuiken, T., Fouchier, R. A., Amonsin, A., Payungporn, S., Noppornpanth, S., Wattanodorn, S., Theambooniers, A., Tantilertcharoen, R., Pattanarangsan, R., Arya, N., Ratanakorn, P., Osterhaus, D. M. and Poovorawan, Y. 2004. Avian influenza H5N1 in tigers and leopards. Emerg. Infect. Dis. 10: 2189-2191. [Medline] [CrossRef]

19. Klopfleisch, R., Wolf, P. U., Uhl, W., Gerst, S., Harder, T., Starick, E., Vahlenkamp, T. W., Mettenleiter, T. C. and Teifke, J. P. 2007. Distribution of lesions and antigen of highly pathogenic avian influenza virus A/Swan/Germany/R65/06 (H5N1) in domestic cats after presumptive infection by wild birds. Vet. Pathol. 44: 261-268. [Medline] [CrossRef]

20. Lee, N., Chan, P. K., Wong, C. K., Wong, K. T., Choi, K. W., Joynt, G. M., Lam, P., Chan, M. C., Wong, B. C., Lui, G. C., Sin, W. W., Wong, R. Y., Lam, W. Y., Yeung, A. C., Leung, T. F., So, H. Y., Yu, A. W., Sung, J. J. and Hui, D. S. 2011. Viral clearance and inflammatory response patterns in adults hospitalized for pandemic 2009 influenza A(H1N1) virus pneumonia. Antivir. Ther. 16: 237-247. [Medline] [CrossRef]

21. Levy, D. E. and García-Sastre, A. 2001. The virus battles: IFN induction of the antiviral state and mechanisms of viral evasion. Cytokine Growth Factor Rev. 12: 143-156. [Medline] [CrossRef]

22. Monteiro, J. M., Harvey, C. and Trinchieri, G. 1998. Role of interleukin-12 in primary influenza virus infection. J. Virol. 72: 4825-4831. [Medline]

23. Peiris, J. S., Cheung, C. Y., Leung, C. Y. and Nicholls, J. M. 2009. Innate immune responses to influenza A H5N1: friend or foe? Trends Immunol. 30: 574-584. [Medline] [CrossRef]

24. Perrone, L. A., Plowden, J. K., García-Sastre, A., Katz, J. M. and Tumpey, T. M. 2008. H5N1 and 1918 pandemic influenza virus infection results in early and excessive infiltration of macrophages and neutrophils in the lungs of mice. PLoS Pathog. 4: e1000115. [Medline] [CrossRef]

25. Schmittgen, T. D. and Livak, K. J. 2008. Analyzing real-time PCR data by the comparative $\mathrm{C}(\mathrm{T})$ method. Nat. Protoc. 3: 1101-1108. [Medline] [CrossRef]

26. Semenzato, G. 1990. Tumour necrosis factor: a cytokine with multiple biological activities. Br. J. Cancer 61: 354-361. [Medline] [CrossRef]

27. Seo, S. H. and Webster, R. G. 2002. Tumor necrosis factor alpha exerts powerful anti-influenza virus effects in lung epithelial cells. J. Virol. 76: 1071-1076. [Medline] [CrossRef]

28. Seo, S. H., Hoffmann, E. and Webster, R. G. 2002. Lethal H5N1 influenza viruses escape host anti-viral cytokine responses. Nat. Med. 8: 950-954. [Medline] [CrossRef]

29. Song, D., Kang, B., Lee, C., Jung, K., Ha, G., Kang, D., Park, S., Park, B. and Oh, J. 2008. Transmission of avian influenza virus (H3N2) to dogs. Emerg. Infect. Dis. 14: 741-746. [Medline] [CrossRef]

30. Steidle, S., Martínez-Sobrido, L., Mordstein, M., Lienenklaus, 
S., García-Sastre, A., Stäheli, P. and Kochs, G. 2010. Glycine 184 in nonstructural protein NS1 determines the virulence of influenza A virus strain PR8 without affecting the host interferon response. J. Virol. 84: 12761-12770. [Medline] [CrossRef]

31. Szretter, K. J., Gangappa, S., Lu, X., Smith, C., Shieh, W. J., Zaki, S. R., Sambhara, S., Tumpey, T. M. and Katz, J. M. 2007. Role of host cytokine responses in the pathogenesis of avian H5N1 influenza viruses in mice. J. Virol. 81: 2736-2744. [Medline] [CrossRef]

32. Varga, Z. T., Grant, A., Manicassamy, B. and Palese, P. 2012. Influenza virus protein PB1-F2 inhibits the induction of type I interferon by binding to MAVS and decreasing mitochondrial membrane potential. J. Virol. 86: 8359-8366. [Medline] [CrossRef]

33. Vivier, E., Raulet, D. H., Moretta, A., Caligiuri, M. A., Zitvogel, L., Lanier, L. L., Yokoyama, W. M. and Ugolini, S. 2011. Innate or adaptive immunity? The example of natural killer cells. Sci- ence 331: 44-49. [Medline] [CrossRef]

34. Wan, H., Sorrell, E. M., Song, H., Hossain, M. J., RamirezNieto, G., Monne, I., Stevens, J., Cattoli, G., Capua, I., Chen, L. M., Donis, R. O., Busch, J., Paulson, J. C., Brockwell, C., Webby, R., Blanco, J., Al-Natour, M. Q. and Perez, D. R. 2008. Replication and transmission of H9N2 influenza viruses in ferrets: evaluation of pandemic potential. PLoS One 3: e2923. [Medline] [CrossRef]

35. Watford, W. T., Moriguchi, M., Morinobu, A. and O'Shea, J. J. 2003. The biology of IL-12: coordinating innate and adaptive immune responses. Cytokine Growth Factor Rev. 14: 361-368. [Medline] [CrossRef]

36. World Health Organization 2013. Human infection with influenza A(H7N9) virus in China—update [cited 2013 April 10]. Available from http://www.who.int/csr/don/2013_04_10/en/ index.html. 